\title{
Accelerated Mortgage Process: An Analytical Evaluation
}

Natalia Boliari, (Email: natalia.boliari@manhattan.edu), Manhattan College, NYC Kudret Topyan, (Email: kudret.topyan@manhattan.edu), Manhattan College, NYC

\section{INTRODUCTION}

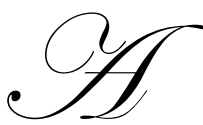

traditional mortgage ${ }^{1}$ process is a simple contract between the mortgage provider (mortgager) and the mortgage holder (mortgagee). Contract, in general, is initiated upon "closing" of the real estate sale, and the payments are scheduled monthly; with the first payment is due at the first day of the first month after the closing date. The most common traditional mortgage in the US is a 30-year fixed rate loan. Others are 20,15 , or 10 year fixed-rate ones or flexible rate loans with several different maturities.

Lately, however, an interesting approach to classical mortgage contracts surfaced. This is a system generally called as "accelerated mortgage". In general, the accelerated mortgage process is handled by an independent company working between a mortgage provider and its customers. One can illustrate this process as follows: Let X be a leading company in this field. $\mathrm{X}$-and the clearing house of $\mathrm{X}$ behind the process- establishes a variety of strategic partnerships. In general, the process starts with a letter a mortgagee receives from his/her mortgage company suggesting to participate in an accelerated mortgage process ${ }^{2}$. Company $\mathrm{X}$ that works with the original mortgage provider claims that since each participant in this transaction benefits, a 'win-win' scenario always exists whenever a company's payment flows involve X-based payment services. In this case, X provides advantages to three parties: X, its partner-clients, and the homeowner. X can offer its clients a cost-effective, fully-bundled service that enables them to increase fee income, reduce loan delinquencies, receive early warning of problem loans and improve investor security, as well as lower administrative costs by replacing paper checks with electronic transactions. Accelerated mortgage programs promise to save thousands of dollars while paying off a mortgage years earlier; application forms are very simple, savings are very clear, no refinancing is required, and no commitment to a present mortgage company is required. It is presented as a clearly superior system in which every mortgagee benefits.

Within a few years, probably due to the cooperation of several important financial institutions the accelerated mortgage companies work with, this program gained a great deal of popularity and the number of participants increased exponentially ${ }^{3}$. They have alliances with more than 25 financial institutions as of 2004, with mortgage loan portfolios ranging from 20,000 to 2,000,000 customers, and literally millions of mortgage holders are the participants of this sort of programs. Many important mortgage providers in the U.S. are part of this program now. Bank of America Mortgage, Citicorp, Chase Manhattan Mortgage Corporation, GE Capital, Nations Bank, Countrywide, Washington Mutual, Home-Side Lending, National City Mortgage, Sun-Trust Mortgage, First Horizon Home Loans, and HSBC are among the major participants of this process.

At the same time, supporting reviews appeared in most reputable media. Within the last few years, almost every consumer magazine, periodical, or daily paper have been writing about this process; among them one can count The Consumer, The Wall Street Journal, Dollar Stretcher, Chronicle, Globe, Washington Herald, Money, Florida Today, Detroit News, Bank Rate Monitor, Debt Smart, Associated Press, Money Wise, New York Times, Business Week, Parents, Consumer Reports, Washington Post, Los Angeles Times, USA Today, New York Post, Forbes, etc. Nevertheless, one cannot see an analytical evaluation of these programs and/or their material benefits to mortgage holders. This paper analyzes the "Accelerated Mortgage Process" (AMP) offered by many banks and other mortgage providers in the US today, together with other related technical issues in the mortgage industry. Section two explains the participation and cost comparisons of these programs. Section three provides a survey and details of the claimed program benefits. Section four explains the process and performs an analytical evaluation, and section five concludes. 


\section{PARTICIPATION AND COST COMPARISONS}

The cost of participation in an accelerated mortgage program in general changes a little depending on the name of the participating institution but will not present radical differences. Here is a partial list showing the program cost of major participants:

Washington Mutual: Customers can set up a biweekly schedule prior to closing or enroll in the Equity Accelerator Program, which allows customers to pay half of their mortgage payments every two weeks by electronic draft. Cost: \$295 upfront, plus \$5 per month service fee. The pay-as-you-go version is \$9 per month. (Dana, 2002)

Wells Fargo Home Mortgage: Will allow customers to make a payment every two weeks without enrolling in a biweekly program. Customers must specify that the payment is to go toward the mortgage. Also offers Home Equity Enhancement Program to automatically draft half of the mortgage payment every two weeks. Cost: $\$ 295$, plus $\$ 2.50$ per transaction. The pay-as-you-go version is $\$ 4.15$ per transaction. (Dana, 2002)

Chase Manhattan Mortgage Corporation: Allows customers to send a half-payment every two weeks, but each homeowner "really needs to talk to their service agent," says Greg Harrington, senior vice president, mortgage operation. Chase also offers Equity Accelerator, which automatically drafts half a payment every two weeks. Cost: \$295 up front, plus \$2.50 per transaction. Pay-as-you-go program is \$9 per month. (Dana, 2002)

Bank of America Mortgage: The only way to make biweekly payments is to set up a biweekly loan initially or to enroll in the Bank of America Accelerator Program, which drafts half of the mortgage payment every two weeks. Cost: $\$ 379$ up front. Pay-as-you-go version is $\$ 3.75$ per transaction. (Dana, 2002) At Bank of America, about 50,000 customers are enrolled in one of the company's biweekly payment services as of 2002, according to Julie Davis, a company spokesperson. Davis could not quantify an increase in enrollment but says interest is rising because customers like being forced to budget -- especially during a recession.

Countrywide Credit Industries: Customers may send a half-payment every two weeks, but with most loans one full payment must be received by the 15th of the month. Countrywide offers Pay Plan 26, which will draft half of the mortgage payment automatically every two weeks. Cost: $\$ 2$ per transaction. (Dana, 2002) Countrywide Home Loans offers a biweekly payment service, but instead of using a service provider, it administers its own equity accelerator plan. Denise Sandoval, vice president of payment services, estimates the company has 18,000 customers on the service called PayPlan26 in 2002, with more than 2,000 signing up each month. "It's growing by leaps and bounds," she says. Under PayPlan26, Countrywide customers don't have an enrollment expense but do pay a $\$ 2$ transaction fee.

First Horizon Home Loans: Either $\$ 295$ one time fee plus $\$ 5.42$ monthly participation fee, or as an alternative, $\$ 9$ monthly participation fee but no $\$ 295$ one time fee.

Depending on the plan, fees could be even larger. In some cases, they can be as high as $\$ 500$ for enrolling and $\$ 9$ per month in transaction fees. Exhibit 1 shows a sample program cost provided by an Accelerated Mortgage provider (AM), mailed to a mortgage holder.

Exhibit 1:

\begin{tabular}{|c|c|}
\hline \multicolumn{2}{|c|}{ Program Cost - Accelerated Mortgage } \\
\hline One-Time Lifetime Program Fee & $\$ 295$ \\
\hline Monthly Program Fee & $\$ 5.42 /$ month \\
\hline
\end{tabular}

Please note that, the total program cost for this loan with 13 years +5 months remaining period is $\$ 295+(161 \times 5.42)=\$ 1167.62$

\section{SURVEY AND DETAILS OF BENEFITS}

It would be helpful to start with exploring the nature of information presentation. Explanatory information sent to potential clients emphasizes the "savings" and "convenience". In short, this program saves you money, it is 
convenient; and enrolling it costs you very little. As a potential participant, all you need is to sign up for the program; there will be no closing costs, no survey, and no credit check. An insignificant registration fee plus a few dollars of monthly fee are all you have to pay.

One can use the information from one accelerated mortgage company's brochure to underline the nature of the offer: "We can help you. Our new payment option, Equity Accelerator, makes debt reduction convenient and most importantly... easy on your budget. It is a proven savings program which requires no changes to your current mortgage. The following chart summarizes how you will personally save time and money by using Equity Accelerator ${ }^{4}$." The cost of this service is a "Lifetime Enrollment Fee" of $\$ 295$ plus $\$ 2.50$ per payment.

Another example is Equity Accelerator ${ }^{\circledR}$ from Nations Bank, telling that, one could save interest on a mortgage by converting to a biweekly payment plan. The NationsBank plan have no enrollment fee but costs $\$ 3.75$ for each of the 26 payments per year. That's $\$ 97.50$ a year for a program that may last as many as 25 plus years.

The process is almost identical but the cost changes slightly depending on the participating institution. The detail of the process however is not easy to locate in solicitation brochures. An analytical approach can easily decode the "process" if the details are provided in the brochure. This will be covered in the next two sections.

Unfortunately, most of the resources available to consumers evaluate AMP quite superficially, producing suggestions that cannot be supported by facts. A summary survey yields the following: "A bi-weekly mortgage is best for financially sophisticated home buyers, for move-up home buyers and for anyone who wants faster equity build up... It's a great disciplinary tool. In a way, it's like a Christmas Club." (New York Times); "What started as a mortgage lender's marketing gimmick is on its way to becoming the hottest home loan of the decade. It's the bi-weekly mortgage. Bi-weeklies reduce interest expense and build home equity faster." (USA Today); "When repaid on a biweekly schedule, a $\$ 70,000$ mortgage at $10.5 \%$ annual interest produces a savings of $\$ 60,000$ compared with a standard 30-year payback." (Wall Street Journal); "The only way you can justify a 30 year mortgage is with a biweekly payoff." (Los Angeles Times); "The result on a \$100,000, 30-year mortgage at 10\%, for example, is that you can burn your mortgage in just under 21 years and save \$78,359 in interest." (Money) "The Federal National Mortgage Association (Fannie Mae) believes this type of mortgage could appeal to many homebuyers who want to reduce interest payments over the life of the loan, and build up equity faster... a bi-weekly program establishes a structure for speedier payments." (Wall Street Journal); "Whether you already have a mortgage or are in the market for a new loan, you can probably save tens of thousands of dollars by 'investing' in your mortgage. If you took out a $\$ 100,000$ bi-weekly mortgage instead of a regular 30-year mortgage at $10.5 \%$ interest, you could save nearly $\$ 86,000$ in interest over the life of the loan." (Consumer Reports); "The simple fact is that a bi-weekly mortgage not only saves the home buyer a bundle, but makes him or her a homeowner much sooner than the traditional monthly mortgage does." (Parents); States that "You Can Save a Considerable Amount of Money" through this plan. (Business Week); "Bi-Weekly Payments are recommended" (Forbes); A biweekly mortgage - sometimes called an accelerated mortgage - is a superb way to shorten a loan and save money. You pay half your normal payment - every two weeks. (New York Post); "Extra mortgage payments save money" (Powell, Associated Press, 2001).

All of the above sources including reputable names such as The Wall Street Journal, New York Times, and Consumer Reports are suggesting the program by simply calling it "biweekly mortgage" implying that the magic lies behind "biweekly payments". On the other hand, none of the above sources has published an analytical study evaluating the validity of the claims or showing how a potential participant would benefit if participates.

An alternative group consists of a generally less known but more specialized consumer sources, and makes a much better analysis of the biweekly program. One may

call this group as the "group of disapproval." Here are a few comments from this group: They do a little math trick to force you to pay more (Bilker, 2000) "It doesn't make financial sense. "Every time you pay a bill out of your checking account, you pay a $\$ 4.15$ convenience charge. To enjoy this extra convenience, you pay a modest $\$ 49$ enrollment fee. Is that a deal or what?" (Cagey Consumer) "Don't pay any money to a third party to help you set up a biweekly 
mortgage," says Anthony Hsieh, chief executive of Home Loan Center, a California-based online lender. "Welcome to the Age of Non Service Banking, brought to you by the miracle of direct mail marketing.

Bankers, like flam artists of yore, are now seeking ways to get you to pay for something you can do for free. (Burns, 1998) "People look for ways to get you to write a \$195 check." (Lewis, 2003); "In this whole prepayment arena, the one thing that has always perplexed me is people that participate in prepayment plans," says Steve Rhode, president of Debt Consolidators of America. "They pay $\$ 300$ upfront just to get in a prepayment plan when it's something that they can easily do themselves." (Larson, 1998); "It's just another opportunity to pay someone for something you don't need," said Marc Eisenson, author of The Banker's Secret, a guide to mortgage pre-payment techniques. He says you can get the same results -- or better -- by adding a few bucks every time you write your mortgage payment check. Just fill in the amount where it says "additional principal" on your payment slip. "No lender is going to take the money every two weeks regardless of who you sign a contract with," Eisenson said. "And if you want automatic withdrawal, your banker or mortgage holder likely will do it for free." Eisenson added: ""It's insane. It's unfair. It's not exactly dishonest... but the deceit is in the implication that you won't save the money (by prepayment) without paying them", he said, describing biweekly mortgage plans. (Preddy, 2001).

However, there is still no study analyzing the validity of the claims, or showing how a potential participant would be affected if participates. Their disapproval points are generally focused on the unnecessary fee schedule and the worthless service, since one can do this easily without any help from a third party. This paper is an analytical attempt to show that the process should not be used since the potential participant would clearly be worse off.

\section{THE PROCESS AND AN ANALYTICAL EVALUATION}

\section{The Process}

The following example shows a special analysis sent to a mortgage company's customer showing the "present mortgage" situation versus the "accelerated one," and the total benefits calculation. This page is more specific and includes detailed information about a present mortgage. Exhibits 2, 3, and 4 present the information on invitation letter of the program.

Exhibit 2:

\begin{tabular}{|c|c|c|c|}
\hline \multicolumn{4}{|c|}{ Your Current Home Loan } \\
\hline Monthly Principal/Interest & 708.21 & Loan Type & Fixed \\
\hline Escrow/Other Accounts & 377.37 & Current Interest Rate & $6.000 \%$ \\
\hline Monthly Payment & 1085.58 & Current Loan Balance & $83,636.42$ \\
\hline Bi-Weekly Transfer & 545.29 & Original Loan Balance & $83,925.00$ \\
\hline Loan Origination Date & $29-$ Oct-2002 & \multicolumn{2}{|c|}{ Estimated Activity to Date } \\
\hline Loan Origination Term & 15 Years & Principal Paid to Date & 288.58 \\
\hline Loan Payment Due Date & 01 & Interest Paid to Date & $1,254.54$ \\
\hline & & Total Payments to Date & $1,543.12$ \\
\hline
\end{tabular}

Prepared as of: 1/17/2003

Exhibit 3:

\begin{tabular}{|c|c|c|c|c|}
\hline \multicolumn{5}{|c|}{ Your Existing Payment vs. Accelerated Mortgage } \\
\hline Program Year & $\begin{array}{c}\text { Existing Equity } \\
\text { Growth }\end{array}$ & $\begin{array}{c}\text { Accelerated Equity } \\
\text { Growth }\end{array}$ & $\begin{array}{c}\text { Accelerated Equity } \\
\text { Advantage }\end{array}$ & $\begin{array}{c}\text { Cumulative Interest } \\
\text { Saved }\end{array}$ \\
\hline 5 & $20,523.84$ & $25,801.78$ & $5,277.94$ & 687.83 \\
\hline 10 & $47,818.16$ & $61,328.03$ & $13,509.87$ & $3,491.86$ \\
\hline 12 & $65,464.39$ & $83,925.00$ & $18,460.61$ & $6,008.38$ \\
\hline 14 & $83,925.00$ & ---- & ---- & $6,263.82$ \\
\hline
\end{tabular}


Exhibit 4:

\begin{tabular}{|c|c|}
\hline \multicolumn{2}{|c|}{ Summary Of Your Program Savings } \\
\hline Interest Savings & $\$ 6,262.82$ \\
\hline Term Reduction & 2 Years 4 Months \\
\hline Equity Advantage & $\$ 13,509.87$ Additional Equity in 10 Program Years \\
\hline
\end{tabular}

AM (Accelerated Mortgage - our sample company) explains the process: AM will electronically deduct a portion of your mortgage payment from your designated checking account after each payday, every two weeks. We will then automatically make each payment for you based on the monthly due date. By making payments this way, you accumulate extra funds that are applied directly to principal. Of course, you can build equity faster than scheduled without paying a fee for this program, by making extra payments to reduce your loan principal. This program is designated to make it easy for you by automatically making extra principal payments that you may not always remember to do. And, you can choose a schedule that fits your pay cycle." (Estimated Personal Benefits Statement from AM)

In detail, the service provided by AM is a biweekly mortgage payment program ${ }^{5}$. What they do to earn their service charges is to have your money transmitted from your bank account to their bank account, hold on to it for a while, and then transmit the amount due on your original mortgage company when it becomes due. Once again, they are a completely independent entity from your original mortgage company. Under the bi-weekly program, the first payment you make will have to be held at least two weeks so they can combine it with the next payment two weeks later. In other words, your first payment will be held in their account for two weeks, then you will make your second bi-weekly payment, AM still holds your payments 2 or 3 more days until the first day of the month.

Originally, you have an ordinary monthly mortgage with, say, XYZ mortgage company, and your, say, January payment is due on February first ${ }^{6}$, but you can delay the January payment until the end of February $15^{\text {th }}$ if the need arises; there is no penalty if you make the payment on or before February $15^{\text {th }}$.

Now with biweekly mortgage, your new company, requires you to automatically transfer the money -half of your monthly mortgage amount- to them at the end of the second week, which means January $14^{\text {th }}$, (they keep this amount in their account, and/or invest it accordingly) then, they will ask for the same amount on January $28^{\text {th }}$.

It is easy to see that, anyone who is using biweekly mortgage plan will have to pay the whole amount quite early compared to the original alternative. In terms of flexibility as well as cost, you are clearly worse of with the biweekly payments.

In addition to the loss of flexibility there is an interest return loss. This is your loss and a material gain for the company handling biweekly mortgage. They can now invest half of your monthly payment for up to 28 days, and the other half for up to 14 days; each and every month, without violating any law or rule. (This is the same as keeping the first biweekly payment for the duration of the mortgage.)

\section{Compounding And Its Effect On The Process}

Certain calculations in the current mortgage systems may be interpreted as contradictory. One very important contradictory calculation deals with the compounding in connection to periodic rate (PR) and effective annual rate (EAR.) In the current system, a mortgage loan has a certain "nominal annual interest rate", and "monthly compounding." In the financial world, compounding is used for convenience as well as proper computation of "interest on interest". Making payments more frequently than "once a year" requires EAR calculations; therefore, failing to make this arrangement will incur certain cost to a party of the contract. While one party suffers, the other one will benefit from this arrangement. As an example, if a bank offers 5 percent nominal annual return for a checking account, and assumes monthly compounding for convenience, it needs to use the "monthly periodic rate equivalent of 5 percent nominal annual rate" (MPRE5NAR). 
This may be figured out by equating the simple definition of EAR to 5 percent nominal annual rate:

$$
E A R=\left[1+\frac{i}{m}\right]^{m}-1=0.05
$$

rearranging terms yields the following equation:

$$
\operatorname{MPRE} 5 N A R=[1+i]^{1 / m}-1
$$

where $\boldsymbol{i}$ is the nominal annual rate, and $\boldsymbol{m}$ is the compounding coefficient. Inserting .05 for $\boldsymbol{i}$ and 12 for $\boldsymbol{m}$ yields 0.0040741237. This implies that, if a bank wants to pay 5 percent effective annual rate for an account, the proper monthly rate to be used must be 0.0040741237 . One common example is the popular CD accounts. If they just use simple monthly periodic rate, which is equal to nominal annual rate divided by monthly compounding factor of 12 , then the effective annual rate for the account would be:

$$
E A R=\left(1+\frac{0.05}{12}\right)^{12}-1=0.0516
$$

or 5.16 percent.

Naturally, the bank will use the MPRE5NAR and will not compensate for the convenience of compounding. Applying the same principal to mortgage contract in the US, one can see that mortgage companies compute the monthly periodic rate but not the effective annual rate for all mortgage loans in US. Naturally this will cost to the mortgage holders. If we use the same $\$ 100,000,8 \%$ annual rate, 30 -years fixed rate contract, then the total interest paid for the loan would be $\$ 164,155$. Using simple monthly periodic rate produces 8.3 percent effective annual rate for the mortgage holder. Alternatively, if one uses MPRE8NAR in place of simple monthly periodic rate, then the total interest paid would be $\$ 139,616$, yielding a difference of $\$ 24,539$ in 30 years, for a $\$ 100,000$ loan.

Therefore, moving from a monthly system into a biweekly system that effectively converts the compounding coefficient from 12 into 26 will produce more dramatic differences in total interest paid to the mortgage company, costing much more to the mortgage holder. Not using EAR for biweekly payments would cost an additional $\$ 7302$ to our mortgage holder. From equations (4) and (5), it is easy to see that using EAR produces the total interest charges of $\$ 156,739$, versus today's system that produces the total interest charges of $\$ 164,041$, yielding a difference of $\$ 7302$.

\section{Timing Of The Payments}

If one uses the year 2001 to show the payment structure of the accelerated system, the biweekly payments need to be made according to Table 6 . The payment schedule will proceed as follows: The process starts on Monday, January $1^{\text {st }}$ and the payments must be made every other Monday, starting with Monday, January 15 . Table 6 shows "payment Mondays", shaded in light grey. In other words, the shaded areas show Mondays in which biweekly payments are made. Every month we have two of them. July and December, however, are the months that three payments need to be made during the month. It is important to understand that the accelerated mortgage handler will make extra payments to your mortgage company at the end of July and December. Obviously this makes it hard to understand why a client is forced to make biweekly payments throughout the year if these payments are not deposited biweekly. The answer lies behind the compounding process. If we assume that it is possible to sign up a biweekly mortgage with your original mortgage company, then your biweekly payment would have been $\$ 338.52$, (see the computation details in the next section) but half of your original monthly payment is $\$ 366.88$. You are paying $\$ 28.36$ $\mathrm{X} 2=\$ 56.72$ more every month. In other words, in this scenario, if an intermediary establishes an agreement with your mortgage company that the payments will be made on biweekly basis, then your mortgage company will ask only $\$ 338.52$ biweekly. Therefore, if the monthly collected amount is deposited at the end of the month, then one will have an extra $\$ 56.72$ per month that applies to the principal. 
Exhibit 5 below explains the payment schedule for the sample year of 2001, if payments are collected biweekly and deposited monthly.

Exhibit 5: (Biweekly Payments For The Sample Year Of 2001)

\begin{tabular}{|c|c|c|c|c|c|c|c|c|c|c|c|c|}
\hline 2001 & JAN & FEB & MAR & APR & MAY & JUN & JUL & AUG & SEP & OCT & NOV & DEC \\
\hline Mon & 1 & & & & & & & & & 1 & & \\
\hline Tue & 2 & & & & 1 & & & & & 2 & & \\
\hline Wed & 3 & & & & 2 & & & 1 & & 3 & & \\
\hline Thu & 4 & 1 & 1 & & 3 & & & 2 & & 4 & 1 & \\
\hline Fri & 5 & 2 & 2 & & 4 & 1 & & 3 & & 5 & 2 & \\
\hline Sat & 6 & 3 & 3 & & 5 & 2 & & 4 & 1 & 6 & 3 & 1 \\
\hline Sun & 7 & 4 & 4 & 1 & 6 & 3 & 1 & 5 & 2 & 7 & 4 & 2 \\
\hline Mon & 8 & 5 & 5 & 2 & 7 & 4 & 2 & 6 & 3 & 8 & 5 & 3 \\
\hline Tue & 9 & 6 & 6 & 3 & 8 & 5 & 3 & 7 & 4 & 9 & 6 & 4 \\
\hline Wed & 10 & 7 & 7 & 4 & 9 & 6 & 4 & 8 & 5 & 10 & 7 & 5 \\
\hline Thu & 11 & 8 & 8 & 5 & 10 & 7 & 5 & 9 & 6 & 11 & 8 & 6 \\
\hline Fri & 12 & 9 & 9 & 6 & 11 & 8 & 6 & 10 & 7 & 12 & 9 & 7 \\
\hline Sat & 13 & 10 & 10 & 7 & 12 & 9 & 7 & 11 & 8 & 13 & 10 & 8 \\
\hline Sun & 14 & 11 & 11 & 8 & 13 & 10 & 8 & 12 & 9 & 14 & 11 & 9 \\
\hline Mon & 15 & 12 & 12 & 9 & 14 & 11 & 9 & 13 & 10 & 15 & 12 & 10 \\
\hline Tue & 16 & 13 & 13 & 10 & 15 & 12 & 10 & 14 & 11 & 16 & 13 & 11 \\
\hline Wed & 17 & 14 & 14 & 11 & 16 & 13 & 11 & 15 & 12 & 17 & 14 & 12 \\
\hline Thu & 18 & 15 & 15 & 12 & 17 & 14 & 12 & 16 & 13 & 18 & 15 & 13 \\
\hline Fri & 19 & 16 & 16 & 13 & 18 & 15 & 13 & 17 & 14 & 19 & 16 & 14 \\
\hline Sat & 20 & 17 & 17 & 14 & 19 & 16 & 14 & 18 & 15 & 20 & 17 & 15 \\
\hline Sun & 21 & 18 & 18 & 15 & 20 & 17 & 15 & 19 & 16 & 21 & 18 & 16 \\
\hline Mon & 22 & 19 & 19 & 16 & 21 & 18 & 16 & 20 & 17 & 22 & 19 & 17 \\
\hline Tue & 23 & 20 & 20 & 17 & 22 & 19 & 17 & 21 & 18 & 23 & 20 & 18 \\
\hline Wed & 24 & 21 & 21 & 18 & 23 & 20 & 18 & 22 & 19 & 24 & 21 & 19 \\
\hline Thu & 25 & 22 & 22 & 19 & 24 & 21 & 19 & 23 & 20 & 25 & 22 & 20 \\
\hline Fri & 26 & 23 & 23 & 20 & 25 & 22 & 20 & 24 & 21 & 26 & 23 & 21 \\
\hline Sat & 27 & 24 & 24 & 21 & 26 & 23 & 21 & 25 & 22 & 27 & 24 & 22 \\
\hline Sun & 28 & 25 & 25 & 22 & 27 & 24 & 22 & 26 & 23 & 28 & 25 & 23 \\
\hline Mon & 29 & 26 & 26 & 23 & 28 & 25 & 23 & 27 & 24 & 29 & 26 & 24 \\
\hline Tue & 30 & 27 & 27 & 24 & 29 & 26 & 24 & 28 & 25 & 30 & 27 & 25 \\
\hline Wed & 31 & 28 & 28 & 25 & 30 & 27 & 25 & 29 & 26 & 31 & 28 & 26 \\
\hline Thu & & & 29 & 26 & 31 & 28 & 26 & 30 & 27 & & 29 & 27 \\
\hline Fri & & & 30 & 27 & & 29 & 27 & 31 & 28 & & 30 & 28 \\
\hline Sat & & & 31 & 28 & & 30 & 28 & & 29 & & & 29 \\
\hline Sun & & & & 29 & & & 29 & & 30 & & & 30 \\
\hline Mon & & & & 30 & & & 30 & & & & & 31 \\
\hline Tue & & & & & & & 31 & & & & & \\
\hline
\end{tabular}

\section{The Phrasing}

It seems like calling the system "biweekly" instead of a "monthly" system produces a more convincing savings scenario and confuses the potential client. The source of this confusion seems to be, again, hidden behind the "compounding" factor. One in general tends to think that if the compounding factor increases, interest savings also increase. While this is true, it is not applicable to the case analyzed in here, since the original mortgage company will not be receiving and/or registering the payments on a biweekly basis. For example, a $\$ 100,000,8 \%$ annual, fixed rate, 30 -year mortgage loan $^{8}$ is a loan compounded monthly. Involving in a system such as EA will never modify the 
compounding factor. EA will not make your payments to your original mortgage company "biweekly." They will just collect them from you on a "biweekly" basis. However, if they also make your one-half of monthly payments to your mortgage company on a "biweekly" basis, your benefits increase. EA system simply divides your monthly payment by two and sets this amount as the amount you need to pay on biweekly basis. If one needs to use just the power of compounding, then they should compute your payment accordingly: each payment must be computed using the compound factor of 26 , and payments must be made on a biweekly basis.

One may like to see the reference figure showing total savings if biweekly payments are actually registered as biweekly by your original mortgage company. Arranging the terms of equation (1) yields the following the biweekly payment amount for our original $\$ 100,000$ mortgage example used above.

$$
P M T=\$ 100,000 /\left[\frac{1-\left(1+\frac{.08}{26}\right)^{-780}}{\left(\frac{.08}{26}\right)}\right]
$$

Where 26, the compounding factor, is the number of biweekly periods in one year, 780 is the total numbers of biweekly periods in the life of a mortgage loan (30 years). Biweekly payment, therefore, is equal to $\$ 338.52$. Total interest paid then is $\$ 164,042$ compared to $\$ 164,155$. This shows, naturally, a very negligible difference ( $\$ 113$ difference for the life of the loan!) from a regular monthly system. However, if you make half of your monthly payment (half of $\$ 733.76$, your monthly payment under traditional monthly contract) biweekly, instead of the required payment of $\$ 338.52$ obtained from equation (6), then your payment would be $\$ 366.88$ or $\$ 28.36$ more on biweekly basis. Making $\$ 28.36$ extra biweekly payments, will lower the total interest paid down to $\$ 117,860$, a remarkable difference that is attributable solely on the extra payments of the mortgage holder.

The second confusion point lies behind the similarity of the definitions of "biweekly" and "twice a month." If you are not a careful observer, you will not notice the difference and may assume that "biweekly" is "twice a month". However, in general, this is true only ten out of twelve months in a year. At least twice every year, as explained by Exhibit 6, you will have to make three biweekly payments in one month. Exhibit 6 shows those 24 out of 25 years. One will have to make 2 extra payments in a year, and one out of 25 years, three extra payments are required. A potential client can easily be confused that "biweekly" means "twice a month." One can see this in Table 2 for year 2001. Assuming that a client signed up for EA on December 31, 2000, and will make his/her first payment two weeks from that day - in other words, every other Monday - then, in July and December, our client will have to make three biweekly payments. (See Exhibit 6) Paying 50\% more in a month twice a year may not be easy on one's monthly budget, and in general, it hurts much more than paying, say, 1/12 more of your usual monthly payment every month.

Therefore, one could say that biweekly mortgage companies are not warning the potential clients properly. They say that "the service they provide can be done by the client himself; but they are just making it simple for their clients by automating the process for them." This warning is missing two important facts: First, it fails to spell out clearly that the client will have to make three biweekly payments in at least two out of twelve months (each payment is equal to one-half of their regular monthly payment.) Second, it fails to mention the way they make the payments to your real mortgage company. A potential client thinks that since they pay to the accelerated mortgage company on a biweekly basis, the accelerated process provider also pays to the original mortgage company biweekly. This is important for two reasons: First, if payments are made biweekly to the original mortgage company, benefits are greater. Second, a potential client thinks that there are many biweekly payments to be made every year; therefore, it is worth paying a fee to the biweekly payment arranger to handle these payments. In fact, the accelerated mortgage company makes exactly twelve payments to your real mortgage company, just like you do, originally. Ten out of these twelve payments are regular monthly payments; two of them are 1.5 times your original monthly payments. This reality reduces your burden for saving thousands of dollars of interest charges into writing different amounts - an amount equal to 1.5 times the usual amount - on two out of twelve checks. If this is clearly stated in the solicitation 
material sent to the potential customer, it would be much less likely that the mortgagee would not want to sign up and pay literally thousands of dollars just for that.

Exhibit 6: Extra Payment Months For A Biweekly Payment Schedule

That Starts At December 31, 2000, And Pays Every Other Monday

\begin{tabular}{|c|c|c|c|}
\hline Year & $1^{\text {st }}$ Extra Payment Month & $2^{\text {nd }}$ Extra Payment Month & $3^{\text {rd }}$ Extra Payment Month \\
\hline 2001 & JULY & DECEMBER & \\
\hline 2002 & JULY & DECEMBER & \\
\hline 2003 & JUNE & DECEMBER & \\
\hline 2004 & MAY & NOVEMBER & \\
\hline 2005 & MAY & OCTOBER & \\
\hline 2006 & MAY & OCTOBER & \\
\hline 2007 & APRIL & OCTOBER & \\
\hline 2008 & MARCH & SEPTEMBER & \\
\hline 2009 & MARCH & AUGUST & \\
\hline 2010 & MARCH & AUGUST & \\
\hline 2011 & JANUARY & AUGUST & \\
\hline 2012 & JANUARY & JULY & DECEMBER \\
\hline 2013 & JULY & DECEMBER & \\
\hline 2014 & JUNE & DECEMBER & \\
\hline 2015 & JUNE & NOVEMBER & \\
\hline 2016 & MAY & OCTOBER & \\
\hline 2017 & MAY & OCTOBER & \\
\hline 2018 & APRIL & OCTOBER & \\
\hline 2019 & APRIL & SEPTEMBER & \\
\hline 2020 & MARCH & AUGUST & \\
\hline 2021 & MARCH & AUGUST & \\
\hline 2022 & JANUARY & AUGUST & \\
\hline 2023 & JANUARY & JULY & \\
\hline 2024 & APRIL & SEPTEMBER & \\
\hline 2025 & MARCH & SEPTEMBER & \\
\hline
\end{tabular}

It is our opinion that not disclosing the facts properly confuses the potential clients and make them think that biweekly payment arranger is doing a remarkable job therefore it is worth the money paid to them.

This paper also questions the treatment of escrow for taxes and insurances on the mortgage. Mortgage contracts, almost always, require the mortgagee to hold an escrow account with the mortgage company. Mortgage holders make monthly payments into this account to cover property taxes and insurances they have to pay for the real estate in question. When the taxes and insurance payments are due, your mortgage company will pay them on your behalf. In a regular mortgage, escrow is collected monthly. When you authorize an accelerated mortgage company, they will compute your biweekly payment by adding up your monthly mortgage payment and your monthly escrow amount and dividing this amount by two. Therefore, this process will also produce an extra monthly escrow amount every year. An accelerated mortgage company, for instance, EA Program fails to explains how this amount is used. One can only think of a few possibilities: i) Return this amount back to you at the end of every year. ii) Keep it until the end of the year and deposit it against the principal. The first possibility is ignored, since it would not make sense to first collect an extra amount and then return it back to you. However, the second option needs attention. Exhibit 7 shows total gains under different assumptions.

(Original Loan Balance: \$83,925. Current Loan Balance: \$83,626.42. Principal Paid to Date: 288.58.Interest Paid to Date: 1,254.54. Interest Rate: 6\%. Loan Origination Term: 15 years. Monthly Principal and Interest: \$708.21. Escrow: \$377.37. Biweekly Transfer: \$545.29) 
Exhibit 7: Comparing The Benefits Of Four Alternative Mortgage Arrangements

\begin{tabular}{|c|c|c|c|c|}
\hline Mortgage Type & Regular Mortgage & Biweekly $^{1}$ & Biweekly $^{2}$ & $\mathbf{A} \mathbf{M}^{3}$ \\
\hline Duration in Months & 179 & 159 & 151 & 151 \\
\hline Total Interest Paid & $44,386.80$ & $39,080.40$ & $36,837.32$ & $38,122.98$ \\
\hline Interest Savings & benchmark & $5,306.40$ & $7,549.48$ & 6263.82 \\
\hline Periodic Payment & 708.21/monthly & 354.11/biweekly & $\begin{array}{c}\text { 354.11/biweekly+\$37 } \\
\text { 7.37/annual }\end{array}$ & Unknown \\
\hline
\end{tabular}

1 No extra escrow. The extra payments are assumed to be made when three "Pay Mondays" fall in a month. (see Exhibits 5 and 6 for details). 2 One extra escrow. One month escrow of $\$ 377.35$ is assumed to be deposited against the principal, at the end of every year. $3 \mathrm{AM}$ (Accelerated Mortgage)This information is obtained from an AM information brochure.

Clearly, if an extra escrow is not collected, total interest savings would be $\$ 5,306.40$, not $\$ 6,263.82$ as claimed by the brochure; and if an extra escrow per year is collected and credited to the account as part of the December payment every year, then the total interest savings would be $\$ 7,549.48$, again, not $\$ 6,263.82$ as claimed. All possible transaction fees except the first $\$ 295$ are excluded from these calculations since EA collects them additionally. Exhibits 8, 9, and 10 show the calculations in more detail.

Exhibit 8: Biweekly Additions Are Made According To Exhibit 6.

Extra Escrow (\$377.37) Is On Dec. Biweekly Payment Is \$542.79*

\begin{tabular}{|c|c|c|c|c|c|}
\hline Year & Starting Balance & Monthly Interest & $\begin{array}{c}\text { (TA) Total } \\
\text { Amount }\end{array}$ & $\begin{array}{c}\text { TA minus } \\
\text { Payment }\end{array}$ & Month \\
\hline 1 & $83,626.42$ & 418.18 & $84,054.60$ & $83,346.40$ & 1 \\
\hline 1 & $81,473.43$ & 416.73 & $83,763.13$ & $83,054.92$ & 2 \\
\hline 10 & $29,959.97$ & 149.79 & $30,109.77$ & $29,047.46$ & 1 \\
\hline 10 & 29047.46 & 145.24 & $29,192.69$ & $28,484.49$ & 2 \\
\hline 13 & $1,308.71$ & 6.54 & $1,315.26$ & 607.05 & 5 \\
\hline 13 & 607.05 & 3.03 & 610.09 & -452.22 & 6 \\
\hline
\end{tabular}

Total Interest Paid: $\$ 36,837.32$. Interest saved: $\$ 44,386.80-36,837.32=7,549.48$.

*Excel file showing the complete worksheet is available upon request.

Exhibit 9: Regular Mortgage. Monthly Payment Is \$708.207*

\begin{tabular}{|c|c|c|c|c|c|}
\hline Year & Starting Balance & Monthly Interest & $\begin{array}{c}\text { (TA) Total } \\
\text { Amount }\end{array}$ & $\begin{array}{c}\text { TA Minus } \\
\text { Payment }\end{array}$ & Month \\
\hline 1 & $83,636.42$ & 418.18 & $84,054.60$ & $83,346.40$ & 1 \\
\hline 1 & $83,346.40$ & 416.73 & $83,763.13$ & $83,054.92$ & 2 \\
\hline 10 & $42,238.32$ & 211.19 & $42,449.51$ & $41,741.30$ & 1 \\
\hline 10 & $41,741.30$ & 208.71 & $41,950.01$ & $41,241.80$ & 2 \\
\hline 15 & 704.96 & 3.52 & 708.21 & 0.27 & 1 \\
\hline 15 & 0.27 & - & - & - & 2 \\
\hline
\end{tabular}

Total Interest Paid: $\$ 44,386.80 \quad$ "Excel file showing the complete worksheet is available upon request.

Exhibit 10: Biweekly Additions Are Made On Dec. No Escrow. Biweekly Payment Is \$542.79*

\begin{tabular}{|c|c|c|c|c|c|}
\hline Year & Starting Balance & Monthly Interest & $\begin{array}{c}\text { (TA) Total } \\
\text { Amount }\end{array}$ & TA Minus Payment & Month \\
\hline 1 & $83,636.42$ & 418.18 & $84,054.60$ & $83,346.39$ & 1 \\
\hline 1 & $83,346.39$ & 416.73 & $83,763.13$ & $83,054.92$ & 2 \\
\hline 10 & $34,236.78$ & 171.63 & $34,498.41$ & $33,436.10$ & 1 \\
\hline 10 & $33,436.10$ & 167.18 & $33,603.28$ & $32,895.07$ & 2 \\
\hline 13 & $1,001.35$ & 5.01 & $1,006.36$ & 298.15 & 2 \\
\hline 13 & 298.15 & 1.49 & 299.64 & -408.57 & 3 \\
\hline
\end{tabular}

Total Interest Paid: $\$ 39,080.40$. Interest saved: $\$ 44,386.80-\$ 39,080.40=\$ 5,306.40$.

${ }^{*}$ Excel file showing the complete worksheet is available upon request. 


\section{CONCLUSION}

One may first question the rationale of making additional payments to a mortgage. Making additional payments and "building equity" faster by paying down your mortgage principal makes financial sense if you have the opportunity cost free spare cash around. A mortgage ordinarily is a lower cost debt one incurs relative to other forms of debts such as a car loan, home improvement loan, credit card loans etc. If one has any higher interest debt, paying additional money towards the principal will actually increase one's total interest costs, and that increase will generally occur in the form of non-tax-deductible interest. Since the mortgage interest is, in general tax deductible, a higher portion of the interest will be non-tax-deductible, costing one an amount functional with one's marginal tax rate.

In other words, if one has any non-mortgage consumer debt, the enrollment to this sort of programs is not suggested. One should remember that almost any form of savings wisely invested will earn more than the mortgage interest saved by the prepayment. In addition to that, even if one does not have any higher cost debt right now, one must be sure that he or she is not planning on taking out any other consumer loans for the remainder of the mortgage term. Making extra payments is similar to investing in a long-term CD with no option to withdraw. An extra amount paid to the mortgage company will not change one's net worth at the moment. It will just transfer the flexible and investable financial funds into rigid home equity that may be interpreted as under-leveraged real estate investment. On the other hand, if one is not carrying any consumer debt, and comfortable with the amount of funds he/she has set aside for emergencies, and would like to pay down the mortgage, extra payments may be suggested.

Second, one may question the benefits of using accelerated mortgage programs such as EA. Confusing advertising material and undisclosed information failing to explain what exactly these programs are doing for the client may be misleading. Even if one satisfies the financial requirements and is suggested to participate, it is not easy to justify the program cost. These programs will easily cost $\$ 1500$ to $\$ 2000$ to each participant. Therefore one might say that what a potential user of accelerated mortgage loses is not limited to the loss of flexibility of payments dates, but also a material increase in the cost of the debt. Since the lender will generally be required to accept your extra payments without any extra charges, this would not require a third party to handle this.

In our opinion, programs such as biweekly mortgages are using confusing advertising material to attract customers. A potential customer should be made aware that it is not a biweekly mortgage, and the original mortgage company is not receiving the biweekly payments on a biweekly basis. It is the participant of the accelerated mortgage programs who pays biweekly, and the company that handles this is doing a job equivalent to writing two different amounts on two out of twelve checks per year for the client.

Although it is impossible to guess the exact number of participants in these programs, in the light of their advertisement information, one may guess at least 1,000,000 mortgage holders are part of the accelerated programs right now, generating close to two billion dollars total fees. This is two billion dollars paid due to confusing information provided in the advertisement brochures. Not registering biweekly payments immediately will cost about another $\$ 113$ per customer producing a total loss of about $\$ 113$ million. This may be expanded if one computes the interest loss due to paying early to the biweekly payment arranger.

In short, due to the technicalities inherent to interest rate computations, mortgage holders in general fail to understand several related issues that may cost them thousands of dollars. One may say that consumers in this area are not properly protected and certain regulations or at least a generally accepted "code" should be initiated to protect the mortgage holders.

Another point is the unnecessary collection of biweekly payments. A biweekly mortgage company is collecting the payments biweekly but not sending them to the mortgage company on a biweekly basis. It forces one to pay biweekly and this is clearly an inconvenience for the mortgagee in addition to the inconvenience created by eliminating the privilege of being late up to 15 days every month, if the need arises. One will pay the total fees well above $\$ 1,500$ to a company that collects the money biweekly and therefore creates inflexibilities for the mortgagee and does not send in the biweekly payments on a biweekly basis, causing interest payment losses on mortgagee's side. 


\section{FOOT NOTES}

1 A mortgage is a temporary, conditional pledge of property to a creditor as security for performance of an obligation or repayment of a debt. The word mortgage comes from the Old French words mort, "dead," and gage, "pledge." It seems that it had to do with the doubtfulness of whether or not the mortgagor will pay the debt. If the mortgagor does not, then the land pledged to the mortgagee as security for the debt "is taken from him for ever, and so dead to him upon condition, \&c. And if he doth pay the money, then the pledge is dead as to the [mortgagee]." This etymology, as understood by 17th-century attorneys, of the Old French term mortgage, which US adopted, may well be correct. The term has been in English much longer than the 17th century, being first recorded in Middle English with the form mortgage and the figurative sense "pledge" in a work written before 1393. (The American Heritage $\left.{ }^{\circledR}, 2000\right)$

1 Such as Bi-Saver, Equity Accelerator, etc.

1 "We're seeing a huge jump in it," says content and media manager with Paymap, an electronic payment services company noted above, that administers equity accelerator plans for financial institutions such as Citigroup, Bank of America and Washington Mutual. In February 1999 Paymap had 168,500 subscribers for its equity accelerator product. Three years later, 512,500 people have signed up. "As more people hear about it, we get calls asking if they can do it too," he says. Paymap and other service companies work as middlemen between banks and customers, processing payments and handling the back-office paperwork. Banks get a cut of the revenue obtained from fees that service companies charge homeowners. Because of the profits and increased customer demand, banks have become more interested in Paymap's services. "Three years ago, there were 21 major banks doing this with Paymap," Hilbert says. "Now we have 32." (Gillin, Eric 2002)

$1 \mathrm{AE}$ is the name Paymap uses for their accelerated mortgage system. Paymap is the best known company in this industry. In February 1999 , Paymap had 168,500 subscribers for its AE program. Three years later, 512,500 people have signed up. Paymap is a First Data company since 2002.

1 They also have alternative weekly, monthly etc. versions.

1 Mortgages are ordinary annuities, and payments are made at the end of the periods.

1 Also called APR or Annual Percentage Rate.

1 A "\$100,000 mortgage loan with 30 years fixed term, 8 percent annual interest rate," is a typical mortgage contact in US. One may use the following formula with the natural assumption of monthly compounding to compute the constant monthly payment of this loan:

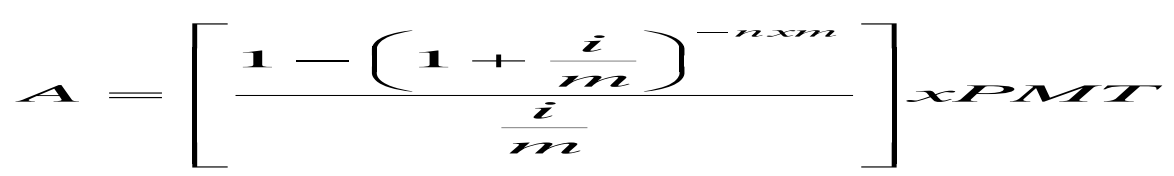

where $\mathrm{A}$ is the initial mortgage amount, $\mathrm{i}$ is the nominal annual interest rate, $\mathrm{n}$ is the number of years in the contract, $\mathrm{m}$ is the compounding factor, ( $\mathrm{m}=12$ for monthly compounding), and PMT is the monthly mortgage payment. Inserting $\$ 100,000$ for A, .08 for i, 30 for n, 12 for m, one can solve the above equation easily for PMT, the monthly payment. (PMT = $\$ 733.76$ ) In other words, in a traditional contract, $\$ 733.76$ needs to be paid back at the end of each and every month, until the loan is fully amortized. In a 30 -year fixed rate contract, this would be equal to $360 \mathrm{X} \$ 733.76=\$ 264,155.25$. ( $\$ 164,155.25$ is the total interest paid) While $\$ 733.76$ will not change for the life of the loan, the composition, or internal components of this payment, namely, the portion applied to principal, and the portion applied to interest, will change every month. Clearly, at the starting point of any contract, portion applied to interest would be at its highest point, and then declines with time. One may use equation (2) to figure out the components of the first payment.

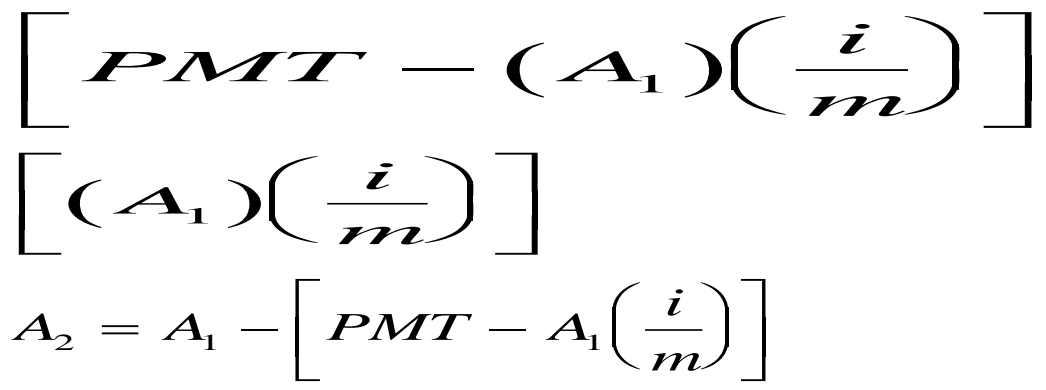

where $\mathrm{A} 1$ is the initial balance, A2 is the balance by the end of the first month, and so on. Equation (2a) shows the amount applies to principal; equation (2b) shows the amount applies to accumulated interest; and equation (2c) shows the principal balance once the first payment is made. Using the numbers in our example, equation (2a) yields $\$ 67.09$, equation ( $2 \mathrm{~b}$ ) yields $\$ 666.67$, and finally equation (2c) yields $\$ 999,932.91$. If we carry out these calculations for the next two months, the amount applied to principal would be $\$ 67.54$ and $\$ 67.99$, while the amount applied to interest would be $\$ 666.22$ and $\$ 665.77$ for months two and three, respectively. Therefore, making an additional payment of $\$ 67.54$ with the first month's payment will shorten the life of your mortgage loan one full month and saves you $\$ 666.22$ in interest. However, this amount would go down every month, making the contribution less important every month. Therefore, it is not only the amount of payment plays an important role in paying back a mortgage, but also "when this payment is made." 
1 A mortgage is a temporary, conditional pledge of property to a creditor as security for performance of an obligation or repayment of a debt. The word mortgage comes from the Old French words mort, "dead," and gage, "pledge." It seems that it had to do with the doubtfulness of whether or not the mortgagor will pay the debt. If the mortgagor does not, then the land pledged to the mortgagee as security for the debt "is taken from him for ever, and so dead to him upon condition, \&c. And if he doth pay the money, then the pledge is dead as to the [mortgagee]." This etymology, as understood by 17th-century attorneys, of the Old French term mortgage, which US adopted, may well be correct. The term has been in English much longer than the 17th century, being first recorded in Middle English with the form mortgage and the figurative sense "pledge" in a work written before 1393. (The American Heritage®, 2000) 2 Such as Bi-Saver, Equity Accelerator, etc.

3 "We're seeing a huge jump in it," says content and media manager with Paymap, an electronic payment services company noted above, that administers equity accelerator plans for financial institutions such as Citigroup, Bank of America and Washington Mutual. In February 1999 Paymap had 168,500 subscribers for its equity accelerator product. Three years later, 512,500 people have signed up. "As more people hear about it, we get calls asking if they can do it too," he says. Paymap and other service companies work as middlemen between banks and customers, processing payments and handling the back-office paperwork. Banks get a cut of the revenue obtained from fees that service companies charge homeowners. Because of the profits and increased customer demand, banks have become more interested in Paymap's services. "Three years ago, there were 21 major banks doing this with Paymap," Hilbert says. "Now we have 32." (Gillin, Eric 2002)

$4 \mathrm{AE}$ is the name Paymap uses for their accelerated mortgage system. Paymap is the best known company in this industry. In February 1999, Paymap had 168,500 subscribers for its AE program. Three years later, 512,500 people have signed up. Paymap is a First Data company since 2002.

5 They also have alternative weekly, monthly etc. versions.

6 Mortgages are ordinary annuities, and payments are made at the end of the periods.

7 Also called APR or Annual Percentage Rate.

8 A "\$100,000 mortgage loan with 30 years fixed term, 8 percent annual interest rate," is a typical mortgage contact in US. One may use the following formula with the natural assumption of monthly compounding to compute the constant monthly payment of this loan:

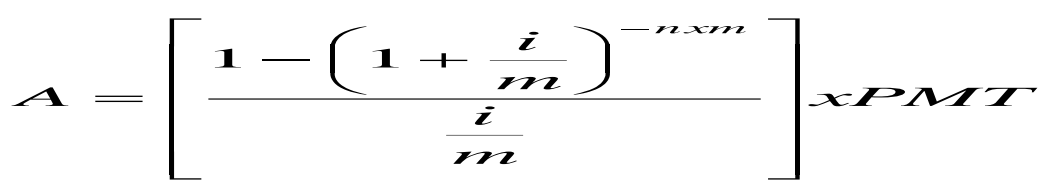

where $\mathrm{A}$ is the initial mortgage amount, $\mathrm{i}$ is the nominal annual interest rate, $\mathrm{n}$ is the number of years in the contract, $\mathrm{m}$ is the compounding factor, (m=12 for monthly compounding), and PMT is the monthly mortgage payment. Inserting $\$ 100,000$ for A, .08 for i, 30 for $\mathrm{n}, 12$ for $\mathrm{m}$, one can solve the above equation easily for PMT, the monthly payment. (PMT $=\$ 733.76$ ) In other words, in a traditional contract, $\$ 733.76$ needs to be paid back at the end of each and every month, until the loan is fully amortized. In a 30-year fixed rate contract, this would be equal to $360 \mathrm{X} \$ 733.76=\$ 264,155.25$. ( $\$ 164,155.25$ is the total interest paid) While $\$ 733.76$ will not change for the life of the loan, the composition, or internal components of this payment, namely, the portion applied to principal, and the portion applied to interest, will change every month. Clearly, at the starting point of any contract, portion applied to interest would be at its highest point, and then declines with time. One may use equation (2) to figure out the components of the first payment.

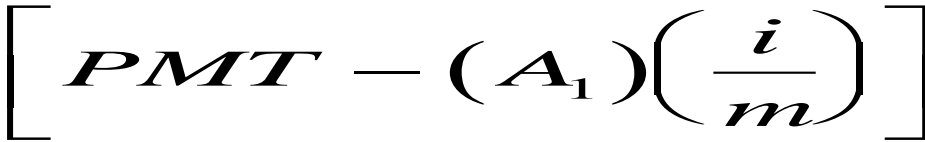

$$
\begin{aligned}
& {\left[\left(\Delta_{1}\right)\left(\frac{i}{m}\right)\right]} \\
& A_{2}=A_{1}-\left[P M T-A_{1}\left(\frac{i}{m}\right)\right]
\end{aligned}
$$

where $\mathrm{A} 1$ is the initial balance, $\mathrm{A} 2$ is the balance by the end of the first month, and so on. Equation (2a) shows the amount applies to principal; equation (2b) shows the amount applies to accumulated interest; and equation (2c) shows the principal balance once the first payment is made. Using the numbers in our example, equation (2a) yields $\$ 67.09$, equation (2b) yields $\$ 666.67$, and finally equation (2c) yields $\$ 999,932.91$. If we carry out these calculations for the next two months, the amount applied to principal would be $\$ 67.54$ and $\$ 67.99$, while the amount applied to interest would be $\$ 666.22$ and $\$ 665.77$ for months two and three, respectively. Therefore, making an additional payment of $\$ 67.54$ with the first month's payment will shorten the life of your mortgage loan one full month and saves you $\$ 666.22$ in interest. However, this amount would go down every month, making the contribution less important every month. Therefore, it is not only the amount of payment plays an important role in paying back a mortgage, but also "when this payment is made." 